\title{
Analisis Faktor-Faktor yang Memengaruhi Risiko Likuiditas pada Bank Umum Syariah di Indonesia
}

\section{Analysis of factors affecting the liquidity risk in Islamic banks in Indonesia}

\section{Regita Nur Fitriani}

Program Studi D4 Keuangan Syariah, Politeknik Negeri Bandung

Email: regita.nur.ksy16@polban.ac.id

\section{Dimas Sumitra Danisworo}

Jurusan Akuntansi, Politeknik Negeri Bandung

Email: dimas.danisworo@polban.ac.id

\begin{abstract}
This research was conducted to analyze what factors affecting the liquidity risk in Islamic Banks in Indonesia. In this study, the measurement of liquidity risk. will be seen from other factors that can affects liquidity risk including Cash Ratio (CsR), Size of Bank (SOB), Third Party Funds (DPK), Capital Adequacy Ratio (CAR), Net Working Capital (NWC), and Investment (INV). The research method used in this research is a quantitative descriptive analysis uses the Eviews 9 program. The object of this analysis is twelve Islamic Banks in Indonesia which have been operating from 2014-2018. The analysis technique used is multiple regression analysis with Random Effect Model (REM) regression model. The results of this study indicate that CsR, SOB, and NWC have a significant effect on liquidity risk. While DPK, CAR, and INV have an insignificant effect on liquidity risk.
\end{abstract}

Keywords: Islamic Banks; Liquidity Risk

\section{Pendahuluan}

Bank syariah menurut Undang-Undang Republik Indonesia Nomor 21 Tahun 2008 merupakan bank yang menjalankan kegiatan usahanya berdasarkan prinsip syariah, terdiri atas dua jenis yaitu bank umum syariah dan bank pembiayaan rakyat syariah. Bank syariah mulai diperhatikan baik oleh masyarakat maupun oleh pemerintah saat bank syariah pertama di Indonesia yaitu Bank Muamalat berhasil bertahan dari terjangan krisis moneter yang menimpa Indonesia pada tahun 1998 tanpa bantuan dari pemerintah (Nofinawati, 2015).

Dengan melesatnya perkembangan perbankan syariah khusunya di Indonesia, pastinya akan berpengaruh pada tingkat perekonomian. Bank syariah sebagaimana layaknya bank konvensional merupakan lembaga yang memiliki fungsi intermediasi antar masyarakat, menghimpun dana dari masyarakat yang memiliki kelebihan dana ke dalam bentuk simpanan untuk disalurkan kembali kepada masyarakat yang membutuhkan dana dalam bentuk pembiayaan, hal ini dilakukan dengan tujuan meningkatkan taraf hidup masyarakat dan untuk menyeimbangkan likuiditas aset dan liabititas. Sebagai lembaga kepercayaan masyarakat yang kegiatan operasionalnya lebih banyak menggunakan dana dari masyarakat dibanding modal sendiri, bank dituntut untuk menjaga posisi likuiditas dengan pencapaian rentabilitas yang wajar serta pemenuhan modal yang memadai (Ummah, 2010) dalam (Hijriyani \& Setiawan, 2017). 
Likuiditas itu sendiri ialah salah satu tolak ukur perkembangan dan kemampuan bank dalam memenuhi semua kewajiban, serta memiliki ketersediaan dana ketika diperlukan. Suatu bank mungkin saja dapat kehilangan kepercayaan masyarakat apabila bank tersebut tidak bisa memenuhi kewajibannya secara tepat waktu. Selain itu, likuiditas yang buruk dapat menyebabkan bank mendapatkan peringatan bahkan sanksi dari pihak regulator. Keadaan seperti ini mengharuskan bank untuk mempertaruhkan reputasinya (Annisa \& Adityawarman, 2017). Untuk itu, sebuah keharusan bagi bank untuk menjaga kestabilan kesehatan likuiditas yang dimiliki. Berdasarkan data yang tersaji pada Statistik Perbankan Syariah OJK, posisi likuiditas bank umum syariah sejak tahun 2014 hingga tahun 2018 adalah sebagai berikut:

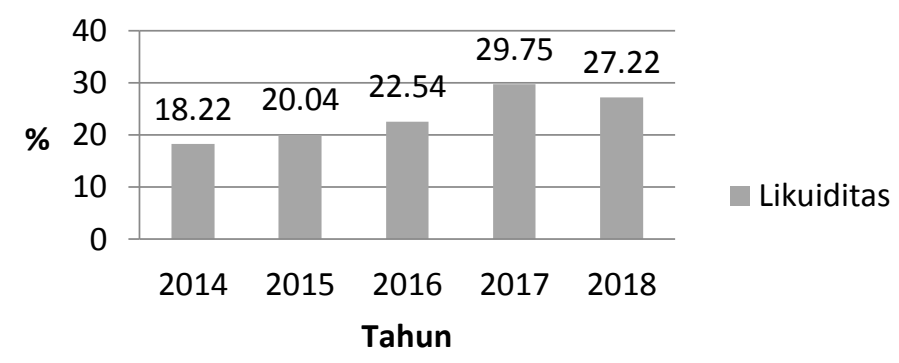

Gambar 1. Posisi Likuiditas BUS di Indonesia Tahun 2014-2018

Sumber: Statistik Perbankan Syariah OJK

Berdasarkan Gambar 1 di atas, dapat diketahui bahwa posisi likuiditas Bank Umum Syariah yang ada di Indonesia dari tahun 2014 sampai 2017 terus mengalami peningkatan, terutama di tahun 2017 terjadi peningkatan yang signifikan menjadi 29,75\% atau bertambah sebesar 7,21\% dari tahun sebelumnya. Namun pada tahun 2018, terjadi penurunan posisi likuiditas Bank Umum Syariah yaitu sebesar 2,53\% menjadi 27,22\%.

Di antara beberapa penelitian yang meneliti faktor-faktor yang memengaruhi risiko likuiditas adalah penelitian yang dilakukan oleh (Alzoubi, 2017) terhadap 42 bank syariah dri 15 negara yang ada di Arab, meneliti Cash Ratio (CASH), Investasi pada surat berharga/Securities (SEC), dan Equity Ratio (EQTY) memiliki pengaruh yang berbanding terbalik dengan risiko likuiditas. Sementara nilai kuadrat dari ukuran bank (SIZE ${ }^{2}$ ), Return on Assets (ROA), dan Bad Financing (BAD) memiliki pengaruh yang berbanding lurus dengan risiko likuiditas. Selain itu, penelitian yang dilakukan oleh (Santoso, Murni, \& Nugrahaningsih, 2015) mengenai faktor Networking Capital, Return on Equity (ROE), dan Return on Assets (ROA) berpengaruh secara signifikan terhadap likuiditas bank syariah sementara ukuran bank dan Capital Adequacy Ratio (CAR) tidak berpengaruh secara signifikan terhadap likuiditas bank syariah.

Berdasarkan keterangan yang telah dipaparkan di atas dan melihat adanya perbedaan dari hasil yang diteliti, maka penulis memutuskan untuk meneliti kembali mengenai risiko likuiditas yang berjudul "Analisis Faktor-Faktor yang Memengaruhi Risiko Likuiditas pada Bank Umum Syariah di Indonesia".

\section{Kajian Pustaka}

\subsection{Bank Syariah}

Bank syariah menurut Undang-Undang Republik Indonesia Nomor 21 Tahun 2008 merupakan bank yang menjalankan kegiatan usahanya berdasarkan prinsip syariah, terdiri atas dua jenis yaitu bank umum syariah dan bank pembiayaan rakyat syariah. Prinsip syariah ini lebih jelas 
diterangkan pada Undang-Undang Republik Indonesia Nomor 10 Tahun 1998 tentang Perbankan pasal 1 butir 13 yaitu aturan perjanjian berdasarkan hukum Islam antar bank dan pihak lain untuk penyimpanan dana dan atau pembiayaan kegiatan usaha, atau kegiatan lainnya yang dinyatakan sesuai dengan syariah.

\subsection{Risiko Likuiditas}

Dalam menjalankan kegiatan usahanya sebagai lembaga intermediasi, bank syariah diwajibkan untuk menjaga posisi likuiditas perusahaannya karena akan berdampak pada kinerja perusahaan. Semakin baik posisi likuiditas yang dimiliki, semakin baik pula kinerja perusahaan tersebut. Namun, baik buruknya posisi likuiditas yang dimiliki bank syariah pasti terdapat risiko didalamnya. Seperti pada Peraturan Bank Indonesia Nomor 13/23/PBI/2011 tentang penerapan manajemen risiko pada bank umum syariah dan unit usaha syariah, risiko likuiditas merupakan risiko yang diakibatkan ketidakmampuan bank dalam memenuhi kewajiban yang jatuh tempo dari sumber pendanaan arus kas dan/atau aset likuid berkualitas tinggi yang dapat diagunkan, tanpa mengganggu aktivitas dan kondisi keuangan bank. Menurut (Danisworo \& Setiawan, 2017), manajemen likuiditas dapat disebabkan oleh beberapa faktor diantaranya kekuatan tekanan likuiditas, persiapan instrumen likuid bank, kondisi bank saat terjadi tekanan likuiditas, dan kemampuan bank untuk mendapatkan sumber likuid baik internal maupun eksternal.

\subsection{Perumusan Hipotesis}

\section{a. Pengaruh Cash Ratio terhadap Risiko Likuiditas}

Cash Ratio ialah rasio untuk mengukur perbandingan antara uang kas dan kewajiban lancar yang dimiliki oleh bank. Semakin besar jumlah uang kas yang dimiliki oleh suatu bank, maka risiko likuidtas akan berkurang karena bank tersebut memiliki kemampuan yang cukup untuk memenuhi permintaan apabila terdapat penarikan dana yang tidak terduga dari nasabah. Menurut penelitian dari (Alzoubi, 2017), cash ratio memiliki pengaruh berbanding terbalik yang signifikan terhadap risiko likuiditas.

\section{b. Pengaruh Size of Bank terhadap Risiko Likuiditas}

Size of Bank digunakan untuk mengukur sebesar apa ukuran suatu bank dengan alat ukur berupa logaritma natural (Ln) dari total aset (Mai \& Setiawan, 2020). Idealnya, bank dengan aset yang banyak akan menghasilkan laba yang lebih banyak pula. Laba yang meningkat tentunya akan meningkatkan posisi likuiditas suatu bank. Dari hasil penelitian yang dilakukan oleh (Masruroh, 2018), size of bank memiliki pengaruh positif signifikan terhadap posisi likuiditas suatu bank yang diproksikan dengan FDR. (Abdo \& Onour, 2018) juga mengatakan bahwa bank size berpengaruh signifikan terhadap risiko likuiditas.

\section{c. Pengaruh Dana Pihak Ketiga terhadap Risiko Likuiditas}

Dana Pihak Ketiga yang berupa giro, tabungan, dan deposito merupakan penghimpunan dana masyarakat yang disimpan di bank. Penghimpunan dana berarti pengumpulan atau pencarian dana dengan cara membeli dari masyarakat luas ke dalam bentuk giro, tabungan, dan deposito (Setiawan, 2018). Pembelian ini dilakukan bank melalui berbagai strategi tertentu untuk menarik minat masyarakat dan menginvestasikan dananya melalui lembaga keuangan bank (Martono, 2010) dalam (Tripuspitorini \& Setiawan, 2020). Dana ini nantinya akan dikelola oleh bank ke dalam bentuk pembiayaan. DPK ialah sumber dana terbesar yang sangat diandalkan oleh bank, karena besarnya jumlah DPK dapat meningkatkan jumlah pembiayaan yang diberikan kepada nasabah. Menurut penelitian (Masruroh, 2018), DPK memiliki pengaruh positif signifikan terhadap likuiditas bank umum syariah yang diproksikan dengan FDR. 


\section{d. Pengaruh Capital Adequacy Ratio terhadap Risiko Likuiditas}

Capital Adequacy Ratio atau CAR ialah alat untuk mengetahui kemampuan bank dalam menyediakan dana jika kemungkinan adanya risiko kerugian (Taruna \& Setiawan, 2019). Idealnya, nilai CAR yang tinggi akan meningkatkan kemampuan bank dalam menghadapi risiko kerugian. Menurut penelitian (Santoso, Murni, \& Nugrahaningsih, 2015) CAR memiliki pengaruh positif terhadap likuiditas bank meskipun hasilnya tidak signifikan. Penelitian (Masruroh, 2018) juga mengatakan bahwa CAR memiliki pengaruh yang positif signifikan.

\section{e. Pengaruh Net Working Capital terhadap Risiko Likuiditas}

Modal kerja bersih atau net working capital mengukur sejauh mana selisih antara aset lancar dan kewajiban lancar. Selisih ini menunjukkan kemampuan bank dalam membayar kewajibannya dalam waktu dekat. Idealnya, besaran NWC tidak rendah dan tidak terlalu tinggi. Menurut penelitian (Santoso, Murni, \& Nugrahaningsih, 2015), net working capital memiliki pengaruh positif secara signifikan terhadap likuiditas.

\section{f. Pengaruh Investment terhadap Risiko Likuiditas}

Investment merupakan suatu pengorbanan yang dilakukan oleh bank pada masa sekarang untuk mendapatkan keuntungan di masa yang akan datang. Jika bank memiliki investasi yang cukup, investasi tersebut dapat digunakan sebagai pengganti uang tunai jika terjadi penurunan posisi likuiditas. Penelitian (Alzoubi, 2017) menunjukkan bahwa investasi pada surat berharga memiliki pengaruh negatif yang signifikan terhadap risiko likuiditas. Sedangkan pada penelitian (Abdo \& Onour, 2018) investasi memiliki pengaruh positif signifikan terhadap risiko likuiditas. berikut:

Berdasarkan penjelasan di atas dapat disimpulkan bahwa hipotesisnya adalah sebagai

H1: Diduga terdapat pengaruh Cash Ratio (CsR) secara parsial terhadap Risiko Likuiditas (RL).

H2: Diduga terdapat pengaruh Size Of Bank (SOB) secara parsial terhadap Risiko Likuiditas (RL).

H3: Diduga terdapat pengaruh Dana Pihak Ketiga (DPK) secara parsial terhadap Risiko Likuiditas (RL).

H4: Diduga terdapat pengaruh Capital Adequacy Ratio (CAR) secara parsial terhadap Risiko Likuiditas (RL).

H5: Diduga terdapat pengaruh Net Working Capital (NWC) secara parsial terhadap Risiko Likuiditas (RL).

H6: Diduga terdapat pengaruh Investment (INV) secara parsial terhadap Risiko Likuiditas (RL).

H7: Diduga terdapat pengaruh Cash Ratio (CsR), Size OfBank (SOB), Dana Pihak Ketiga (DPK), Capital Adequacy Ratio (CAR), Net Working Capital (NWC), dan Investment (INV) secara simultan terhadap Risiko Likuiditas (RL).

\section{Metode Penelitian}

\subsection{Jenis dan Sumber Data}

Pada penelitian kali ini, penulis menggunakan data sekunder berupa data panel tahunan periode 2014 sampai dengan 2018. Jumlah BUS di Indonesia terhitung sampai Desember 2018 berjumlah 14. Namun terjadi perbedaan jumlah BUS pada September 2016 yaitu berjumlah 13 dan pada tahun 2014 berjumlah 12. Oleh karena itu, penulis menentukan bahwa sampel yang akan digunakan pada penelitian ini adalah 12 BUS yang beroperasi dari tahun 2014 sampai dengan tahun 2018 Data tersebut bersumber pada Laporan Keuangan Tahunan BUS yang ada di Indonesia dan 
Laporan Statistik Perbankan Syariah - Otoritas Jasa Keuangan.

\subsection{Operasional Variabel}

Penelitian ini menggunakan variabel-variabel yang meliputi variabel dependen dan variabel independen. Berikut merupakan operasional variabel yang digunakan dalam penelitian ini.

Tabel 1 Operasional Variabel

\begin{tabular}{|c|c|c|}
\hline No & Proksi & Formula \\
\hline 1 & Current Ratio & $\boldsymbol{C R}=\frac{\text { Aktiva Lancar }}{\text { Hutang Lancar }} \times 100 \%$ \\
\hline 2 & Cash Ratio (CsR) & $\boldsymbol{C s} \boldsymbol{R}=\frac{\text { Kas dan Setara Kas }}{\text { Kewajiban Lancar }} \times 100 \%$ \\
\hline 3 & Size of Bank (SOB) & Size of Bank $=\operatorname{Ln}($ Total Aset $)$ \\
\hline 4 & Dana Pihak Ketiga (DPK) & $\boldsymbol{D P K}=$ Giro + Tabungan + Deposito \\
\hline 5 & $\begin{array}{l}\text { Capital Adequacy } \\
\text { (CAR) }\end{array}$ & $\boldsymbol{C A R}=\frac{\text { Modal Bank }}{\text { ATMR }} \times 100 \%$ \\
\hline 6 & Net Working Capital(NWC) & $\boldsymbol{N W C}=$ Aktiva Lancar - Hutang Lancar \\
\hline 7 & Investment (INV) & $\mathbf{I N V}=\frac{\text { Investasi pada Surat Berharga }}{\text { Total Aset }}$ \\
\hline
\end{tabular}

Sumber: Olaban Penulis

\subsection{Metode Penelitian}

Metode penelitian yang digunakan pada penelitian kali ini adalah metode penelitian kuantitatif dengan metode analisis deskriptif dan analisis regresi berganda. Penelitian kuantitatif ini dalam pengumpulan, pengolahan, dan hasilnya berupa data yang didominasi angka. Dalam melakukan penelitian ini, digunakan alat analisis berupa program Eviews9.

\subsection{Analisis Deskriptif}

Menurut Ghozali (2013) dalam (Masruroh, 2018), analisis deskriptif ialah metode untuk menjelaskan suatu data yang dilihat dari rata-rata (mean), standar deviasi, varian, maksimum, minimum, sum, kutosis dan skewness. Analisis ini berfungsi untuk melihat sejauh mana kesesuaian variabel yang diteliti dengan standar yang telah ditetapkan.

\subsection{Estimasi Model Regresi}

Menurut Widarjono (2007) dalam (Sakti, 2018), untuk mengestimasi parameter model dengan data panel, terdapat tiga teknik yang ditawarkan yaitu:

\section{a. Common Effect Model (CEM)}

Teknik common effect merupakan teknik yang paling sederhana untuk mengestimasi parameter model data panel, yaitu dengan mengkombinasikan data cross section dan time series sebagai satu kesatuan tanpa melihat adanya perbedaan waktu dan invidu. Pendekatan yang dipakai dalam model ini adalah metode Ordinary Least Square (OLS).

\section{b. Fixed Effect Model (FEM)}

FEM merupakan salah satu teknik yang mengestimasi data panel dengan menggunakan variabel dummy untuk menangkap adanya perbedaan intersep. Pendekatan ini didasarkan adanya perbedaan intersep antar perusahaan namun intersepnya yaitu antar waktu. Pendekatan yang dipakai dalam model ini adalah metode Least Square Dummy Variable (LSDV). 


\section{c. Random Effect Model (REM)}

REM merupakan salah satu teknik yang mengestimasi data panel dimana variabel gangguan mungkin saling berhubungan antar waktu dan antar individu. Perbedaan antar individu dan antar waktu diakomodasi lewat error. Karena adanya korelasi antar variabel gangguan makan metode OLS tidak bisa digunakan sehingga model ini menggunakan metode Generalized Least Square (GLS).

\subsection{Pemilihan Model Regresi}

Menurut Widarjono (2007) dalam (Sakti, 2018) untuk memilih teknik estimasi data panel terdapat tiga uji yaitu uji chow (uji statistik F), uji hausman, dan uji lagrange mutliplier.

\section{a. Uji Chow}

Uji Chow adalah pengujian untuk menentukan fixed effect model atau common effect model yang paling tepat digunakan dalam mengestimasi data panel. Pengambilan keputusan dilakukan jika nilai prob. $\mathrm{F}<$ taraf signifikansi $(0,05)$, maka model yang paling tepat adalah fixed effect model. Sebaliknya, jika nilai prob. $\mathrm{F}>$ taraf signifikansi $(0,05)$, maka model yang paling tepat adalah common effect model.

\section{b. Uji Hausman}

Uji Hausman adalah pengujian untuk memilih apakah fixed effect model atau random effect model yang paling tepat digunakan dalam mengestimasi data panel. Pengambilan keputusan dilakukan jika nilai probabilitas chi squares $<$ taraf signifikansi, maka fixed effect model yang paling tepat. Namun, jika nilai probabilitas chi squares $>$ taraf signifikansi, maka random effect model yang paling tepat.

\section{c. Uji Lagrange Multiplier}

Uji Lagrange Multiplier (LM) adalah pengujian yang digunakan untuk mengetahui apakah random effect model lebih baik dari pada common effect model. Uji ini dikembangkan oleh Breusch Pagan. Pengambilan keputusan dilakukan jika nilai prob. cross section $>$ taraf signifikansi $(0,05)$, maka common effect model yang paling tepat. Sedangkan apabila nilai prob. cross section $<$ taraf signifikansi $(0,05)$, maka random effect model yang paling tepat.

\subsection{Uji Asumsi Klasik}

Dalam melakukan uji asumsi klasik, terdapat 4 asumsi yang perlu diuji diantaranya uji normalitas, uji autokorelasi, uji heteroskedastisitas, dan uji multikolinearitas.

\section{a. Uji Normalitas}

Uji normalitas merupakan pengujian terhadap kenormalan distribusi data. Uji normalitas dapat dilakukan dengan beberapa metode yaitu histogram residual, kolmogrov smirnov, skewness kurtosis dan jarque-bera.

\section{b. Uji Autokorelasi}

Menurut Nachrowi dan Hardius (2006) dalam (Sakti, 2018), autokorelasi adalah korelasi yang terjadi antar observasi dalam satu variabel. Metode untuk mendeteksi autokorelasi antara lain metode grafik, durbin-watson, run dan lagrange multiplier.

\section{c. Uji Heteroskedastisitas}

Uji heteroskedastisitas digunakan untuk melihat apakah residual dari model yang terbentuk memiliki varians yang konstan atau tidak. Metode untuk medeteksi heteroskedastisitas antara lain metode grafik, park, glesjer, korelasi spearman, goldfels-quandt, breusch-pagan, dan white. 


\section{d. Uji Multikolinearitas}

Multikolinearitas dilakukan pada saat model regresi menggunakan lebih dari satu variabel bebas. Metode untuk mendeteksi multikolinearitas antara lain variance influence factor dan correlation matrix.

\subsection{Uji Hipotesis}

\section{a. Uji t}

Uji t digunakan untuk menguji koefisien regresi secara individu. Jika nilai $t$ hitung $>\mathrm{t}$ tabel atau nilai prob. t-statistik < taraf signifikansi, maka variabel independen berpengaruh secara parsial terhadap variabel bebas.

\section{b. Uji F}

Uji F dilakukan untuk memastikan bahwa model yang dipilih layak untuk menginterpretasikan pengaruh variabel independen terhadap variabel dependen. Jika nilai $\mathrm{F}$ hitung $>$ F tabel atau nilai prob.F-statistik $<$ taraf signifikansi, maka variabel independen secara simultan berpengaruh terhadap variabel dependen.

\subsection{Uji Koefisien Determinasi}

Nilai koefisien determinasi dapat mencerminkan seberapa besar kontribusi yang diberikan oleh variabel independen untuk menjelaskan variabel dependen. Menurut Widarjono (2007) dalam (Sakti, 2018), sebuah model regresi dikatakan baik apabila nilai koefisien determinasi yang dimiliki mendekati 1 (satu).

\section{Hasil dan Pembahasan}

\subsection{Hasil Uji Analisis Deskriptif}

Setelah melakukan uji analisis deskriptif, maka didapat hasil analisis deskriptif seperti tabel di bawah ini:

Tabel 2 Deskriptif Statistik

\begin{tabular}{ccccc}
\hline Variable & Minimum & Maximum & Mean & Std. Deviation \\
\hline RL & -0.2091 & 1.4559 & 0.6467 & 0.3554 \\
\hline CsR & 0.3631 & 4.1917 & 1.2045 & 0.6899 \\
\hline SOB & 13.4029 & 18.4040 & 16.0801 & 1.2546 \\
\hline DPK & 2.8332 & 18.2868 & 15.5068 & 2.0569 \\
\hline CAR & 0.1151 & 1.6307 & 0.2456 & 0.2151 \\
\hline NWC & 7.9014 & 16.5680 & 13.8234 & 1.4777 \\
\hline INV & 0.4267 & 0.9843 & 0.8684 & 0.0985 \\
\hline
\end{tabular}

Sumber: Eviews 9, olahan penulis 


\subsection{Hasil Pemilihan Model Regresi}

a. Uji Chow

\begin{tabular}{|c|c|c|c|}
\hline Effects Test & Statistic & d.f. & Prob. \\
\hline Cross-section F & 7.440819 & $(11,42)$ & 0.0000 \\
\hline Cross-section Chi-square & 64.883612 & 11 & 0.0000 \\
\hline
\end{tabular}

Sumber: Eviews 9, olahan penulis

Berdasarkan hasil uji chow yang tersaji pada tabel di atas, nilai prob. F sebesar 0,0000 atau < dari 0,05 sehingga dapat dikatakan bahwa model regresi yang paling tepat digunakan ialah fixed effect model.

b. Uji Hausman

Tabel 4 Hasil Uji Haussman

Correlated Random Effects - Hausman Test

Equation: DATA

Test cross-section random effects

\begin{tabular}{lrrr}
\hline \hline Test Summary & Chi-Sq. Statistic & Chi-Sq. d.f. & Prob. \\
\hline \hline Cross-section random & 5.249358 & 6 & 0.5123 \\
\hline \hline
\end{tabular}

Sumber: Eviews 9, olahan penulis

Berdasarkan hasil uji hausman yang tersaji pada tabel di atas, nilai prob. chi squares sebesar 0,5123 > 0,05 sehingga dapat dikatakan bahwa model regresi yang paling tepat digunakan adalah random effect model.

c. Uji Lagrange Multiplier

Tabel 5 Hasil Uji Lagrange Multiplier

Lagrange Multiplier Tests for Random Effects

Null hypotheses: No effects

Alternative hypotheses: Two-sided (Breusch-Pagan) and one-sided

(all others) alternatives

\begin{tabular}{|c|c|c|c|}
\hline & \multicolumn{3}{|c|}{ Test Hypothesis } \\
\hline & Cross-section & Time & Both \\
\hline Breusch-Pagan & $\begin{array}{c}25.88250 \\
(0.0000)\end{array}$ & $\begin{array}{l}1.420178 \\
(0.2334)\end{array}$ & $\begin{array}{c}27.30267 \\
(0.0000)\end{array}$ \\
\hline
\end{tabular}

Sumber: Eviews 9, olahan penulis

Berdasarkan hasil uji lagrange multiplier yang tersaji pada tabel di atas, nilai prob. cross section Breusch Pagan sebesar 0,0000 < 0,05 sehingga dapat dikatakan bahwa model regresi yang paling tepat digunakan adalah random effect model. 


\subsection{Hasil Uji Asumsi Klasik}

Dikarenakan pada penelitian ini model regresi yang tepat digunakan adalah random effect model, maka penulis hanya melakukan uji normalitas dan uji multikolineritas.

\section{a. Uji Normalitas}

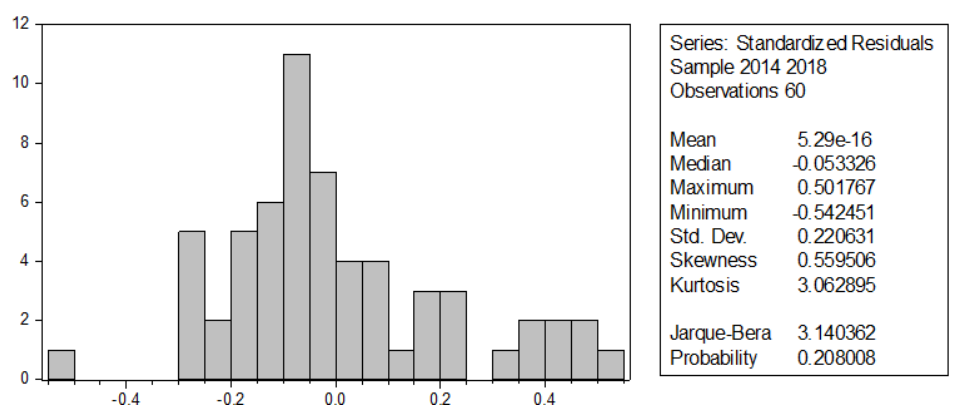

Gambar 2. Hasil Uji Normalitas

Sumber: Eviews 9, olahan penulis

Berdasarkan hasil penelitian di atas, didapat bahwa setelah dilakukan uji normalitas, semua data variabel pada penelitian ini berdistribusi normal. Hal ini dapat ditunjukkan oleh nilai JB di atas sebesar 3,140362 dengan probability 0,208008 atau probabilitas > 0,05. Dengan kata lain, dalam data yang diuji tidak terjadi pelanggaran uji normalitas atau berdistibusi normal.

\section{b. Uji Multikolinearitas}

Tabel 6 Hasil Uji Multikolinearitas

\begin{tabular}{|crrrrrr|}
\hline & X1_CSR & X2_SOB & \multicolumn{1}{c}{ X3_DPK } & X4_CAR & X5_NWC & SQRT_X6_INV \\
\hline \hline X1_CSR & 1.000000 & -0.232251 & -0.352492 & 0.208335 & 0.028740 & 0.116480 \\
X2_SOB & -0.232251 & 1.000000 & 0.735877 & -0.496207 & 0.761093 & -0.191254 \\
X3_DPK & -0.352492 & 0.735877 & 1.000000 & -0.844846 & 0.448697 & 0.180484 \\
X4_CAR & 0.208335 & -0.496207 & -0.844846 & 1.000000 & -0.209228 & -0.141527 \\
X5_NWC & 0.028740 & 0.761093 & 0.448697 & -0.209228 & 1.000000 & -0.244626 \\
SQRT_X6_INV & 0.116480 & -0.191254 & 0.180484 & -0.141527 & -0.244626 & 1.000000 \\
\hline
\end{tabular}

\section{Sumber: Eviews 9, olahan penulis}

Berdasarkan tabel penelitian di atas, setelah dilakukan uji multikolinearitas dengan correlation matrix tidak ada koefisien korelasi yang memiliki nilai di atas 0,8. Sehingga, dapat disimpulkan bahwa tidak ada korelasi antar variabel independen atau dengan kata lain dalam model regresi ini tidak terdapat masalah multikolinearitas.

\subsection{Hasil Uji Hipotesis}

Berdasarkan hasil uji estimasi model regresi dan didapat bahwa random effect model merupakan model yang paling tepat dalam penelitian ini, maka untuk uji hipotesis dan uji koefisien determinasi menggunakan hasil uji random effect model. 
Tabel 7 Hasil Pemilihan Estimasi Model

\begin{tabular}{|c|c|c|c|c|}
\hline \multicolumn{5}{|c|}{$\begin{array}{l}\text { Dependent Variable: LOG_Y_RL } \\
\text { Method: Panel EGLS (Cross-section random effects) } \\
\text { Date: } 08 / 05 / 20 \text { Time: } 15: 40 \\
\text { Sample: } 20142018 \\
\text { Periods included: } 5 \\
\text { Cross-sections included: } 12 \\
\text { Total panel (balanced) observations: } 60 \\
\text { Swamy and Arora estimator of component variances }\end{array}$} \\
\hline Variable & Coefficient & Std. Error & t-Statistic & Prob. \\
\hline $\begin{array}{l}\text { C } \\
\text { X1_CSR } \\
\text { X2_SOB } \\
\text { X3_DPK } \\
\text { X4_CAR } \\
\text { X5_NWC } \\
\text { SQRT_X6_INV }\end{array}$ & $\begin{array}{r}1.141676 \\
0.268430 \\
-0.165271 \\
-0.005656 \\
-0.026333 \\
0.158191 \\
-0.291694\end{array}$ & $\begin{array}{l}0.882652 \\
0.053191 \\
0.062430 \\
0.036072 \\
0.298252 \\
0.027096 \\
0.337949\end{array}$ & $\begin{array}{r}1.293461 \\
5.046577 \\
-2.647298 \\
-0.156798 \\
-0.088292 \\
5.838117 \\
-0.863131\end{array}$ & $\begin{array}{l}0.2015 \\
0.0000 \\
0.0107 \\
0.8760 \\
0.9300 \\
0.0000 \\
0.3920\end{array}$ \\
\hline \multicolumn{5}{|c|}{ Effects Specification } \\
\hline $\begin{array}{l}\text { Cross-section random } \\
\text { Idiosyncratic random }\end{array}$ & & & $\begin{array}{l}0.209058 \\
0.142742\end{array}$ & $\begin{array}{l}0.6820 \\
0.3180\end{array}$ \\
\hline \multicolumn{5}{|c|}{ Weighted Statistics } \\
\hline $\begin{array}{l}\text { R-squared } \\
\text { Adjusted R-squared } \\
\text { S.E. of regression } \\
\text { F-statistic } \\
\text { Prob(F-statistic) }\end{array}$ & $\begin{array}{l}0.659317 \\
0.620749 \\
0.141728 \\
17.09494 \\
0.000000\end{array}$ & \multicolumn{2}{|c|}{$\begin{array}{l}\text { Mean dependent var } \\
\text { S.D. dependent var } \\
\text { Sum squared resid } \\
\text { Durbin-Watson stat }\end{array}$} & $\begin{array}{l}0.188857 \\
0.230140 \\
1.064603 \\
1.236153\end{array}$ \\
\hline
\end{tabular}

Sumber: Eviews 9, olahan penulis

\section{a. Uji t}

Dari hasil output pada tabel di atas, dapat diketahui bahwa variabel CsR, SOB, dan NWC berpengaruh signifikan secara parsial terhadap risiko likuiditas. Hal ini terlihat dari hasil nilai prob. t-statistic yang dihasilkan < taraf signifikansi 0,05 . Sementara itu, variabel DPK, CAR, dan INV tidak berpengaruh signifikan secara parsial terhadap risiko likuiditas, karena nilai pro.t-statistic yang dihasilkan $>$ taraf signifikansi 0,05 .

\section{b. Uji F}

Dari hasil output pada tabel di atas, dapat diketahui bahwa nilai $\mathrm{F}_{\text {hitung }}$ yang didapat adalah sebesar 17,09494 $>\mathrm{F}_{\text {tabel }} 2$ 2,28. Selain itu nilai prob. F-statistic yang diperoleh adalah 0,000000 < taraf signifikansi 0,05. Kedua hasil tersebut menunjukkan bahwa dari keenam variabel independen berpengaruh secara simultan terhadap variabel dependen.

\subsection{Hasil Uji Koefisien Determinasi}

Berdasarkan hasil output yang terdapat pada tabel di atas, dapat diketahui bahwa nilai Adjusted R-squared yang dihasilkan adalah sebesar 0,620749. Hal ini berarti model regresi yang digunakan baik dan secara bersama-sama CsR, SOB, DPK, CAR, NWC, dan INV mempunyai kontribusi untuk menjelaskan Risiko Likuiditas sebesar 62,07\%, sedangkan sisanya sebesar 37,93\% dijelaskan oleh variabel lain yang tidak ikut diteliti dalam model penelitian ini. 


\subsection{Pembahasan Analisis Data}

Berdasarkan hasil uji estimasi model regresi dan hasil perhitungan pada tabel 7 , maka didapatkan persamaan regresi linier berganda sebagai berikut:

$$
\begin{aligned}
& \log R L=1,1417+0,2684 C s R-0,0165 S O B-0,0056 D P K-0,0263 C A R+ \\
& 0,1582 N W C-0,2917 \text { Sqrt }(I N V)
\end{aligned}
$$

Berdasarkan persamaan regresi tersebut didapati nilai konstanta sebesar 1,1417, hal ini berarti jika semua variabel independen dianggap tetap maka nilai log dari risiko likuiditas adalah sebesar 1,1417. Dalam penelitian ini, penulis menggunakan perhitungan current ratio sebagai alat analis risiko likuiditas dimana rumusnya adalah aset lancar dibagi dengan hutang lancar. Semakin tinggi nilai current ratio yang dimiliki, semakin rendah risiko likuiditasnya. Maka dari itu, nilai positif dari konstanta pada persamaan di atas mengandung arti apabila semua variabel independen konstan atau tidak ada perubahan maka nilai current ratio nya sebesar 1,1417 atau dengan kata lain risiko likuiditasnya rendah. Untuk analisis pengaruh dari masing-masing variabel terhadap Risiko Likuiditas dapat dijelaskan sebagai berikut:

\section{a. Pengaruh Cash Ratio terhadap Risiko Likuiditas}

Hipotesis pertama yang diajukan dalam penelitian ini yaitu variabel Cash Ratio secara parsial memiliki pengaruh yang signifikan terhadap Risiko Likuiditas dapat didukung. Sesuai dengan hasil penelitian adanya pengaruh yang signifikan dari Cash Ratio terhadap Risiko Likuiditas. Nilai koefisien regresi variabel CsR memiliki hubungan positif 0,2684 terhadap nilai log RL, artinya setiap perubahan 1\% pada CsR maka nilai log RL akan mengalami peningkatan sebesar 26,84\% dengan asumsi bahwa variabel lain dianggap tetap. Hasil dari penelitian ini serupa dengan penelitian yang dilakukan oleh (Alzoubi, 2017) bahwa Cash Ratio memiliki pengaruh yang signifikan terhadap risiko likuiditas.

\section{b. Pengaruh Size of Bank terhadap Risiko Likuiditas}

Hipotesis yang selanjutnya yaitu variabel Size of Bank secara parsial memiliki pengaruh yang signifikan terhadap Risiko Likuiditas dapat didukung. Sesuai dengan hasil penelitian adanya pengaruh yang signifikan dari Size of Bank terhadap Risiko Likuiditas. Nilai koefisien regresi variabel SOB memiliki hubungan negatif 0,0165 terhadap nilai $\log$ RL, artinya setiap perubahan $1 \%$ pada SOB maka nilai log RL akan mengalami penurunan sebesar 1,65\% dengan asumsi bahwa variabel lain dianggap tetap. Hasil dari penelitian ini serupa dengan penelitian yang dilakukan oleh (Masruroh, 2018) dan (Abdo \& Onour, 2018) bahwa Size of Bank memiliki pengaruh yang signifikan terhadap risiko likuiditas.

\section{c. Pengaruh Dana Pihak Ketiga terhadap Risiko Likuiditas}

Pada penelitian kali ini, variabel DPK didapati memiliki pengaruh yang tidak signifikan terhadap log RL dan arah koefisien yang berlawanan dengan yang dihipotesiskan. Menurut (Sukma, 2013), DPK tidak berpengaruh terhadap risiko likuditas dapat disebabkan oleh ketidakseimbangan antara jumlah dana yang dihimpun dengan jumlah pembiayaan yang diberikan. Semakin rendah tingkat pembiayaan yang disalurkan maka akan semakin rendah tingkat laba yang dimiliki oleh suatu bank. Meskipun penghimpunan dana pihak ketiga cukup signifikan, namun jika tidak diimbangi dengan penyaluran pembiayaan yang cukup maka tingkat risiko likuiditas akan meningkat. Hal tersebut dapat terjadi jika dana yang tersedia tidak dialokasikan secara optimal maka terjadi penimbunan dana. Menurut (Anisa \& Tripuspitorini, 2019) dana pihak ketiga pada bank syariah belum tentu disalurkan untuk meningkatkan porsi pembiayaan kepada nasabah, ada kemungkinan 
bahwa bank tertarik untuk menginvestasikan dana tersebut ke dalam instrumen keuangan lain seperti SWBI, PUAS, dll. Maka dari itu, besar kecilnya dana pihak ketiga belum tentu mencerminkan posisi likuiditas bank. Hasil ini tidak sesuai dengan penelitian yang dilakukan oleh (Masruroh, 2018) yang mengatakan bahwa variabel DPK memiliki pengaruh yang signifikan terhadap likuiditas.

\section{d. Pengaruh Capital Adequacy Ratio terhadap Risiko Likuiditas}

Pada penelitian kali ini, variabel CAR juga didapati memiliki pengaruh yang tidak signifikan terhadap $\log \mathrm{RL}$ dan arah koefisien yang berlawanan dengan yang dihipotesiskan. CAR tidak berpengaruh terhadap risiko likuditas dapat diindikasikan adanya ketidakseimbangan antara dana yang digunakan sebagai cadangan kerugian dan dana yang digunakan untuk ekspansi usaha. Meskipun modal yang dimiliki oleh suatu bank cukup banyak, namun jika tidak diimbangi dengan pengalokasian yang tepat maka akan menurunkan tingkat kemampuan dalam menghadapi risiko kerugian di masa yang akan datang sehingga tingkat risiko likuiditas akan meningkat. Hasil penelitian ini sesuai dengan penelitian yang dilakukan oleh (Santoso, Murni, \& Nugrahaningsih, 2015) yang mengatakan bahwa variabel CAR memiliki pengaruh yang tidak signifikan terhadap likuiditas.

\section{e. Pengaruh Net Working Capital terhadap Risiko Likuiditas}

Hipotesis yang kelima yaitu variabel Net Working Capital secara parsial memiliki pengaruh yang signifikan terhadap Risiko Likuiditas dapat didukung. Sesuai dengan hasil penelitian adanya pengaruh positif yang signifikan dari Net Working Capital terhadap Risiko Likuiditas. Nilai koefisien regresi variabel NWC memiliki hubungan negatif 1,582 terhadap nilai log RL, artinya setiap perubahan 1\% pada NWC maka nilai log RL akan mengalami penurunan sebesar $158,2 \% \%$ dengan asumsi bahwa variabel lain dianggap tetap. Hasil dari penelitian ini serupa dengan penelitian yang dilakukan oleh (Santoso, Murni, \& Nugrahaningsih, 2015) bahwa Net Working Capital memiliki pengaruh yang signifikan terhadap likuiditas.

\section{f. Pengaruh Investment terhadap Risiko Likuiditas}

Selain DPK dan CAR, variabel INV juga memiliki pengaruh yang tidak signifikan terhadap $\log \mathrm{RL}$ dan arah koefisien yang berlawanan dengan yang dihipotesiskan. INV tidak berpengaruh terhadap risiko likuditas dapat memberikan indikasi bahwa dalam memenuhi kewajibannya, bank memiliki dana lain dalam perusahaan yang lebih besar dan lebih memungkinkan dibandingkan dengan dana yang ada pada surat berharga sehingga jumlah dana yang diinvestasikan pada surat berharga tidak dapat mencerminkan posisi likuiditas suatu bank. Hasil penelitian ini tidak sesuai dengan penelitian yang dilakukan oleh (Alzoubi, 2017) dan (Abdo \& Onour, 2018) yang mengatakan bahwa investasi pada surat berharga memiliki pengaruh yang signifikan terhadap likuiditas.

\section{Penutup}

\subsection{Kesimpulan}

Berdasarkan pada rumusan masalah yang telah dirumuskan sebelumnya dan mengacu pada hasil penelitian dan pembahasan yang telah dipaparkan, maka dapat ditarik kesimpulan bahwa variabel independen $\mathrm{CsR}, \mathrm{SOB}$, dan NWC berpengaruh signifikan secara parsial terhadap variabel dependen risiko likuiditas. Sedangkan untuk variabel independen DPK, CAR, dan INV tidak berpengaruh signifikan secara parsial terhadap variabel dependen risiko likuiditas. Namun, dari hasil penelitian menunjukkan bahwa model regresi yang digunakan baik sehingga variabel CsR, SOB, DPK, CAR, NWC, dan INV secara keseluruhan atau simultan berpengaruh signifikan 
terhadap Risiko Likuiditas. Hal ini terlihat dari hasil penelitian yang menunjukkan bahwa variabelvariabel tersebut mempunyai kontribusi untuk menjelaskan Risiko Likuditas sebesar 62,07\%.

\subsection{Saran}

Penulis bermaksud untuk mengajukan beberapa saran yang berkaitan dengan penelitian dan pembahasan yang telah dipaparkan pada bagian sebelumnya khususnya bagi BUS disarankan untuk selalu menjaga posisi likuiditas sebaik mungkin, yaitu dengan mempertimbangkan proporsi jumlah dana yang dihimpun dengan jumlah pembiayaan yang diberikan, karena jika dana yang dimiliki tidak dialokasikan secara optimal maka akan mengakibatkan penimbunan dana. Selain itu, bank juga diharapkan dapat menyeimbangkan antara dana yang digunakan sebagai cadangan dan dana yang digunakan sebagai kegiatan usaha, karena meskipun cadangan cukup banyak apabila tidak diimbangi dengan kegiatan usaha yang lain maka akan menurunkan tingkat kemampuan untuk dalam menghadapi risiko kerugian di masa yang akan datang. Sedangkan bagi pemerintah dalam mengeluarkan dan menerapkan kebijakan diharapkan untuk lebih memperhatikan perbankan syariah terutama bank umum syariah agar dapat berkembang secara signifikan terlebih dalam persaingan dengan bank konvensional juga demi terciptanya perekonomian yang lebih baik.

\section{Daftar Pustaka}

Abdo, M. M., \& Onour, I. A. (2018). Liquidity Risk Management in Islamic Banks : Evidence from Sudan.

Alzoubi, T. (2017). Determinants of liquidity risk in Islamic banks. Banks and Bank System, Vol.12(3): 142-148.

Anisa, L. S., \& Tripuspitorini, F. A. (2019). Analisis Pengarub Dana Pibak Ketiga, Non Performing Finance Murababah, dan Inflasi Terbadap Pembiayaan Murabahab pada Bank Umum Syariah di Indonesia. Jurnal Maps (Manajemen Perbankan Syariah), Vol.3(1): 52-64 .

Annisa, E. I., \& Adityawarman. (2017). Analisis Faktor-Faktor yang Mempengarubi Risiko Likuiditas dan Kinerja (Studi Kasus pada selurub Perbankan Syariah di Indonesia). Diponegoro Journal of Accounting, Vol.6(1): 1-15.

Bank Indonesia. (2011). Peraturan Bank Indonesia Nomor 13/23/PBI/2011 Tentang Penerapan Manajemen Risiko Pada Bank Umum Syariah dan Unit Usaba Syariah.

Danisworo, D. S., \& Setiawan. (2017). Using the Exposure Based Cash Flow At Risk. Approach to Estimate the Liquidity Risk: An Application For the Indonesian Banks. Proceedings of International Conference and Doctoral Colloquium in Finance.

Hijriyani, N. Z., \& Setiawan. (2017). Analisis Profitabilitas Perbankan Syariah di Indonesia sebagai Dampak dari Efisiensi Operasional . Jurnal Kajian Akuntansi, Vol.1, (2): 194-209.

Mai, M. U., \& Setiawan, S. (2020). Pengaruh Struktur Modal Terhadap Kinerja Perusahaan Pada Industri Manufaktur Kriteria Syariah Di Bursa Efek Indonesia. Jurnal Riset Akuntansi dan Keuangan, 8(1), 159-170.

Masruroh, M. (2018). Analisis Faktor-Faktor Yang Mempengarubi Likuiditas Perbankan Syariab di Indonesia (2011-2016). Skripsi.

Nofinawati. (2015). Perkembangan Perbankan Syariah di Indonesia. JURIS, Vol.14(2): 168-183.

Otoritas Jasa Keuangan. (2019). SPS Desember 2018-2014.

Sakti, I. (2018). Analisis Regresi Data Panel Menggunakan Eviews. Modul Eviews 9, 1-25.

Santoso, et. al., (2015). Faktor-Faktor Yang Mempengarubi Likuiditas Perbankan Syariah di Indonesia. . PROSIDING Seminar Nasional dan Call For Papers Ekonomi Syariah"Indonesia Sebagai 


\section{Regita Nur Fitriani, Dimas Sumitra Danisworo}

Kiblat Ekonomi Syariah", 221-231.

Setiawan, S. (2018). Determinan Penentu Pertumbuhan Dana Pihak Ketiga Perbankan Syariah di Indonesia. Jurnal Maps (Manajemen Perbankan Syariah), 1(2), 1-9.

Sukma, Y. L. (2013). Pengaruh Dana Pihak Ketiga, Kecukupan Modal dan Risiko Kredit Terbadap Profitabilitas. Skripsi.

Taruna, R. D., \& Setiawan, S. (2019). Pengaruh Kinerja Keuangan Terhadap Pertumbuhan Laba Bank Umum di Indonesia. Jurnal Accounting Information System (AIMS), 2(1), 69-78.

Tripuspitorini, F. A., \& Setiawan. (2020). Pengarub Faktor Makroekonomi Terhadap Pertumbuhan Dana Pihak Ketiga Pada Bank Umum Syariah di Indonesia. Jurnal Riset Akuntansi dan Keuangan, 8(1): 121-132.

Undang-Undang No. 21 Tahun 2008 tentang Perbankan Syariah.

Undang-Undang Republik Indonesia Nomor 10 Tahun 1998 tentang Perbankan.

Wahyudi, I., Dewi, M. K., Rosmanita, F., Prasetyo, M. B., \& Surya, N. I. (2013). Manajemen Risiko Bank Islam. Jakarta: Salemba Empat. 